\title{
Clostridium aestuarii sp. nov., from tidal flat sediment
}

\author{
Seil Kim, Hyunyoung Jeong and Jongsik Chun \\ School of Biological Sciences and Institute of Microbiology, Seoul National University, 56-1 \\ Shillim-dong, Kwanak-gu, Seoul 151-742, Republic of Korea
}

Correspondence

Jongsik Chun

jchun@snu.ac.kr

\begin{abstract}
A strictly anaerobic, halophilic, motile, endospore-forming, rod-shaped bacterium, designated strain $\mathrm{HY}-45-18^{\top}$, was isolated from a sediment sample of a tidal flat in Korea. The isolate produced butyric acid, propionic acid, glycerol and $\mathrm{H}_{2}$ as fermentation end products from glucose. Strain $\mathrm{HY}-45-18^{\top}$ is halophilic as it was unable to grow in the absence of sea salts. A 16S rRNA gene sequence analysis clearly indicated that the tidal flat isolate is a member of cluster I of the order Clostridiales, which contains the type species of Clostridium, Clostridium butyricum. The closest phylogenetic neighbour of strain $\mathrm{HY}-45-18^{\top}$ was Clostridium ganghwense KCTC $5146^{\top}(96.5 \%$ 16S rRNA gene sequence similarity). Several phenotypic characteristics can be readily used to differentiate the isolate from phylogenetically related clostridia. Therefore, strain $\mathrm{HY}-45-18^{\top}$ represents a novel species of the genus Clostridium, for which the name Clostridium aestuarii sp. nov. is proposed. The type strain is HY-45-18 ${ }^{\top}\left(=\mathrm{IMSNU} 40129^{\top}=\mathrm{KCTC} 5147^{\top}=\mathrm{JCM}\right.$ $\left.13194^{\top}\right)$.
\end{abstract}

The western and south-western coasts of the Korean peninsula consist largely of tidal flats, which are unique among other marine sediments in that they are flooded with seawater but periodically exposed. Culture-independent (Kim et al., 2005, 2004) and culture-dependent (Choi et al., 2006; Park et al., 2005; Yi \& Chun, 2006) studies have shown that the microbial inhabitants of these unique environments are very diverse. A novel anaerobic bacterium, designated strain HY $-45-18^{\mathrm{T}}$, was isolated from a tidal flat sediment and subjected to a polyphasic taxonomic investigation. Here, we report the taxonomic description of this novel member of the genus Clostridium.

Strain HY-45-18 ${ }^{\mathrm{T}}$ was isolated from a sediment sample collected from a tidal flat $\left(37^{\circ} 35^{\prime} 31.9^{\prime \prime} \mathrm{N} 126^{\circ} 27^{\prime} 24.5^{\prime \prime} \mathrm{E}\right)$ on Ganghwa Island, South Korea, using a standard dilution plating method. The isolate was recovered and routinely maintained using marine reinforced clostridial medium (MRCM; Difco) supplemented with $4 \%$ artificial sea salt (Sigma) at $30{ }^{\circ} \mathrm{C}$ under anaerobic conditions.

The primers and PCR conditions and the sequencing method for the 16S rRNA gene were as described previously (Chun \& Goodfellow, 1995). The resulting sequence of strain $\mathrm{HY}-45-18^{\mathrm{T}}$ was aligned manually against sequences obtained from the GenBank database. Phylogenetic trees were inferred using the Fitch-Margoliash (Fitch \& Margoliash, 1967), maximum-likelihood (Felsenstein, 1981),

The GenBank/EMBL/DDBJ accession number for the 16S rRNA gene sequence of strain $\mathrm{HY}-45-18^{\top}$ is $\mathrm{DQ} 126679$. maximum-parsimony (Fitch, 1971) and neighbour-joining (Saitou \& Nei, 1987) methods. Evolutionary distance matrices were generated according to Jukes \& Cantor (1969). The alignment and phylogenetic analysis were carried out using the jPHYDIT program (Jeon et al., 2005) and PAUP 4.0 (Swofford, 1998) as described by Chun et al. (2000). The tree topologies obtained were evaluated by using bootstrap analyses (Felsenstein, 1985) of the neighbourjoining methods (based on 1000 resamplings).

An almost-complete 16S rRNA gene sequence was obtained for strain HY $-45-18^{\mathrm{T}}$ (1390 bp) and used for an initial BLAST search against the GenBank database. The search result clearly indicated that the tidal flat isolate belonged to cluster I of the order Clostridiales defined by Collins et al. (1994); this cluster contains the type species of the genus Clostridium, Clostridium butyricum. The newly determined sequence was then aligned manually (on the basis of the secondary structure of the bacterial $16 \mathrm{~S}$ rRNA) against those of members of cluster I. Phylogenetically, strain HY-45-18 ${ }^{\mathrm{T}}$ was closest to Clostridium ganghwense KCTC $5146^{\mathrm{T}}$ (96.5\% $16 \mathrm{~S}$ rRNA gene sequence similarity). No other species with validly published names showed sequence similarities of $94 \%$ or more. These levels of $16 \mathrm{~S}$ rRNA gene similarity clearly suggest that our isolate represents a novel species of the genus Clostridium. The results of comprehensive phylogenetic analyses are summarized in Fig. 1. Our isolate formed a monophyletic clade with the type strains of $C$. ganghwense, this result being supported by a $99 \%$ bootstrap value and four tree-making algorithms. The type strain of Clostridium grantii was associated with this clade, although 


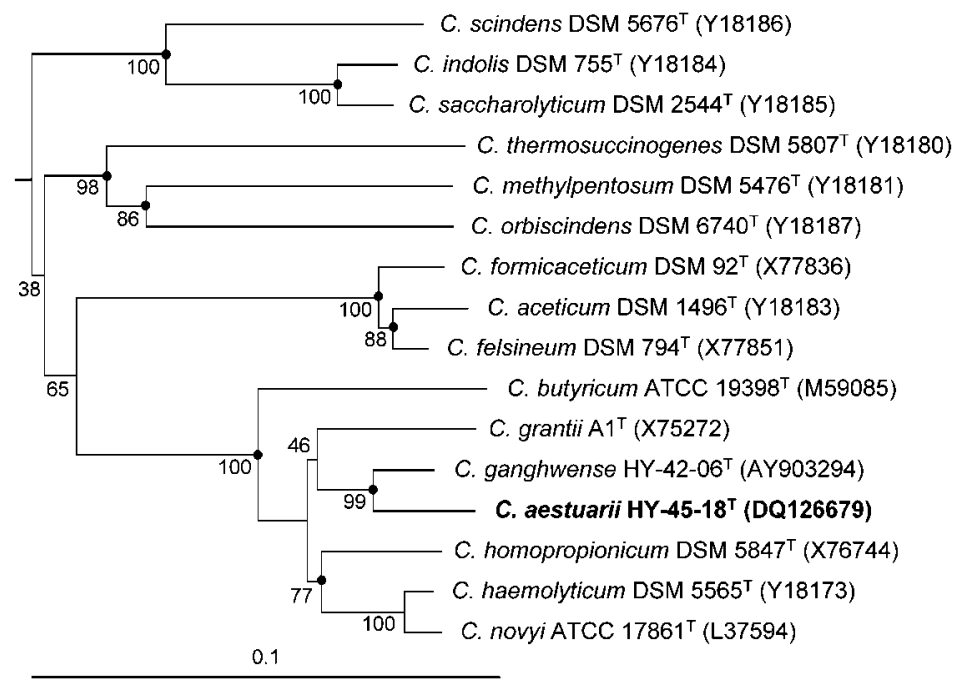

Fig. 1. Neighbour-joining phylogenetic tree, based on almost-complete 16S rRNA gene sequences, showing relationships among strain $\mathrm{HY}-45-18^{\top}$ and members of the genus Clostridium. Percentages of bootstrap support (based on neighbour-joining analyses of 1000 resampled datasets) are shown at nodes; solid circles indicate that the corresponding nodes (groupings) were also recovered in Fitch-Margoliash, maximumlikelihood and maximum-parsimony trees. Clostridium cocleatum DSM $1551^{\top}$ (GenBank accession no. Y18188) was used as an outgroup (not shown). Bar, 0.1 nucleotide substitutions per position.

the corresponding level of bootstrap support was as low as $46 \%$.

The Gram reaction was determined using Gram staining and a KOH test (Johnson et al., 1995; Powers, 1995). Morphology was observed for cells grown on MRCM at $30{ }^{\circ} \mathrm{C}$ by using phase-contrast microscopy and scanning and transmission electron microscopy. The presence of catalase was determined by adding $3 \%(\mathrm{v} / \mathrm{v}) \mathrm{H}_{2} \mathrm{O}_{2}$ to cell smears on standard microscope slides. The $\mathrm{pH}$, temperature and seasalt ranges for growth were determined using MRCM in Hungate tubes. Growth was recorded by measuring the $\mathrm{OD}_{600}$ with a turbidimeter (Biolog). Biochemical tests were performed using the API 20A, API ZYM and API 20NE systems (bioMérieux) in the presence of artificial sea salts

Table 1. Characteristics that differentiate strain $H Y-45-18^{\top}$ from the type strains of C. ganghwense and C. grantii

Strains: 1, strain HY-45-18 ${ }^{\mathrm{T}}$; 2, C. ganghwense KCTC $5146^{\mathrm{T}}$ (data from Kim et al., 2006); 3, C. grantii DSM $8605^{\mathrm{T}}$ (Mountfort et al., 1994). +, Positive; -, negative; ND, no data available.

\begin{tabular}{|lccc|}
\hline Characteristic & $\mathbf{1}$ & $\mathbf{2}$ & $\mathbf{3}$ \\
\hline Gram staining & - & - & + \\
Sea-salt requirement & + & + & - \\
Utilization of: & & & \\
$\quad$ Sucrose & + & - & - \\
Mannose & - & + & + \\
Fructose & - & $\mathrm{ND}$ & + \\
Salicin & - & + & $\mathrm{ND}$ \\
Gelatin & - & + & $\mathrm{ND}$ \\
Cellobiose & - & + & + \\
Fermentation end & Butyrate, & $\mathrm{Glycerol}$, & Acetate, \\
products & propionate, & ethanol, & ethanol, \\
& glycerol, $\mathrm{H}_{2}$ & $\mathrm{CO}_{2}$ & formate, \\
& & & $\mathrm{CO}_{2}$ \\
& & &
\end{tabular}

and vitamin solution (DSM medium 141) according to the instructions of the manufacturer. Lecithinase activity was assayed using MRCM with egg yolk (Oxoid), according to the instructions of the manufacturer.

To determine the substrates utilized and the end products of fermentation, basal medium (Hernandez-Eugenio et al., 2002) was slightly modified to contain the following $\left(1^{-1}\right.$ distilled water): $1 \mathrm{~g} \mathrm{NH}_{4} \mathrm{Cl}, 0.3 \mathrm{~g} \mathrm{~K}_{2} \mathrm{HPO}_{4}, 0.3 \mathrm{~g} \mathrm{KH}_{2} \mathrm{PO}_{4}$, $30 \mathrm{~g}$ sea salt (Sigma), $0.5 \mathrm{~g}$ cysteine hydrochloride, $0.3 \mathrm{~g}$ $\mathrm{Na}_{2} \mathrm{~S} .9 \mathrm{H}_{2} \mathrm{O}, 1 \mathrm{mg}$ resazurin (Sigma), $1 \mathrm{ml}$ trace mineral element solution (DSM medium 318) and $1 \mathrm{ml}$ vitamin solution (DSM medium 141). The final $\mathrm{pH}$ was adjusted to 7 with $10 \mathrm{M} \mathrm{KOH}$. After 2 weeks incubation at $30^{\circ} \mathrm{C}$, the fermentation end products were analysed using an HPLC apparatus (HP1100; Hewlett Packard) equipped with an Aminex HPX-87H (Bio-Rad) column, a refractory index detector and a diode array detector $(210 \mathrm{~nm}) . \mathrm{H}_{2} \mathrm{SO}_{4}$ $(0.005 \mathrm{M})$ was used as the eluent at a flow rate of $0.6 \mathrm{ml}$ $\min ^{-1}$. Carbon dioxide and hydrogen were determined using GC (ACME6000GC; Young Lin) equipped with a Porapak Q (Supelco) column and a thermal conductivity detector. Nitrogen was used as the carrier gas, at a flow rate of $20 \mathrm{ml} \mathrm{min}^{-1}$.

The cells of strain HY- $45-18^{\mathrm{T}}$ were motile rods with peritrichous flagella. The isolate required sea salts for growth and was unable to grow in the presence of $\mathrm{NaCl}$ alone. Detailed morphological, physiological and biochemical characteristics of strain $\mathrm{HY}-45-18^{\mathrm{T}}$ are given in the species description and Table 1.

It is evident from Table 1 that several phenotypic properties readily separate strain $\mathrm{HY}-45-18^{\mathrm{T}}$ from other phylogenetically related species, namely $C$. ganghwense and C. grantii. On the basis of the polyphasic evidence presented here, it is proposed that the tidal flat isolate, strain $\mathrm{HY}-45-18^{\mathrm{T}}$, be classified within a novel species of the genus Clostridium, for which the name Clostridium aestuarii sp. nov. is proposed. 


\section{Description of Clostridium aestuarii sp. nov.}

Clostridium aestuarii (aes.tu.a'ri.i. L. gen. n. aestuarii of the tidal flat).

Cells are strictly anaerobic, chemoheterotrophic, rodshaped $(2-4 \times 0.7-0.8 \mu \mathrm{m})$ and motile with peritrichous flagella. Spores are oval and terminal. Cells are catalasenegative and lecithinase-negative. Colonies are circular and yellowish on MRCM. Requires 1-10\% (w/v) artificial sea salts (optimum $4 \%$ ). Does not grow on reinforced clostridial medium containing $0-5 \%(\mathrm{w} / \mathrm{v}) \mathrm{NaCl}$ alone. The temperature range for growth is $15-30{ }^{\circ} \mathrm{C}$, with optimum growth at $30^{\circ} \mathrm{C}$. The optimum $\mathrm{pH}$ of MRCM for growth is 7.0, and growth occurs between $\mathrm{pH} 5.5$ and 8.5. The $\mathrm{KOH}$ reaction and Gram staining are negative. Cannot grow under aerobic conditions. Nitrate is not reduced. Produces alkaline phosphatase, esterase (C4), esterase lipase (C8), valine arylamidase, acid phosphatase and naphthol-ASBI-phosphohydrolase but not lipase (C14), leucine arylamidase, cystine arylamidase, trypsin, $\alpha$-chymotrypsin, $\alpha$-galactosidase, $\beta$-galactosidase, $\beta$-glucuronidase, $\alpha$-glucosidase, $\beta$-glucosidase, $N$-acetyl- $\beta$-glucosaminidase, $\alpha$-mannosidase or $\alpha$-fucosidase. Indole is not produced and urease is absent. Aesculin is hydrolysed but gelatin is not. Glucose, maltose and sucrose are utilized, but arabinose, cellobiose, fructose, galactose, glycerol, lactose, mannitol, mannose, melezitose, raffinose, rhamnose, ribose, salicin, sorbitol, trehalose and xylose are not hydrolysed. The fermentation end products from glucose are butyric acid, propionic acid, glycerol and $\mathrm{H}_{2}$.

The type strain, HY-45-18 $\left(=\mathrm{IMSNU} 40129^{\mathrm{T}}=\mathrm{KCTC}\right.$ $5147^{\mathrm{T}}=\mathrm{JCM} 13194^{\mathrm{T}}$ ), was isolated from a tidal flat sediment on Ganghwa Island, South Korea.

\section{Acknowledgements}

This work was supported by the Korea Science and Engineering Foundation (KOSEF) through the National Research Laboratory Program funded by the Ministry of Science and Technology (no. M10500000110-06J0000-11010).

\section{References}

Choi, D. H., Kim, Y. G., Hwang, C. Y., Yi, H., Chun, J. \& Cho, B. C. (2006). Tenacibaculum litoreum sp. nov., isolated from tidal flat sediment. Int J Syst Evol Microbiol 56, 635-640.

Chun, J. S. \& Goodfellow, M. (1995). A phylogenetic analysis of the genus Nocardia with $16 \mathrm{~S}$ rRNA gene sequences. Int J Syst Bacteriol 45, 240-245.

Chun, J., Bae, K. S., Moon, E. Y., Jung, S. O., Lee, H. K. \& Kim, S. J. (2000). Nocardiopsis kunsanensis sp nov., a moderately halophilic actinomycete isolated from a saltern. Int J Syst Evol Microbiol 50, 1909-1913.
Collins, M. D., Lawson, P. A., Willems, A., Cordoba, J. J., FernandezGarayzabal, J., Garcia, P., Cai, J., Hippe, H. \& Farrow, J. A. (1994). The phylogeny of the genus Clostridium: proposal of five new genera and eleven new species combinations. Int J Syst Bacteriol 44, 812-826.

Felsenstein, J. (1981). Evolutionary trees from DNA sequences: a maximum likelihood approach. J Mol Evol 17, 368-376.

Felsenstein, J. (1985). Confidence limits on phylogenies: an approach using the bootstrap. Evolution 39, 783-791.

Fitch, W. M. (1971). Toward defining the course of evolution: minimum change for a specific tree topology. Syst Zool 20, 406-416.

Fitch, W. M. \& Margoliash, E. (1967). Construction of phylogenetic trees. Science 155, 279-284.

Hernandez-Eugenio, G., Fardeau, M. L., Cayol, J. L. A., Patel, B. K. C., Thomas, P., Macarie, H., Garcia, J. L. \& Ollivier, B. (2002). Clostridium thiosulfatireducens sp. nov., a proteolytic, thiosulfate- and sulfur-reducing bacterium isolated from an upflow anaerobic sludge blanket (UASB) reactor. Int J Syst Evol Microbiol 52, 1461-1468.

Jeon, Y. S., Chung, H., Park, S., Hur, I., Lee, J. H. \& Chun, J. (2005). jPHYDIT: a JAVA-based integrated environment for molecular phylogeny of ribosomal RNA sequences. Bioinformatics 21, 3171-3173.

Johnson, M. J., Thatcher, E. \& Cox, M. E. (1995). Techniques for controlling variability in gram staining of obligate anaerobes. J Clin Microbiol 33, 755-758.

Jukes, T. H. \& Cantor, C. R. (1969). Evolution of protein molecules. In Mammalian Protein Metabolism, pp. 21-132. Edited by H. N. Munro. New York: Academic Press.

Kim, B. S., Oh, H. M., Kang, H., Park, S. S. \& Chun, J. (2004). Remarkable bacterial diversity in the tidal flat sediment as revealed by $16 \mathrm{~S}$ rDNA analysis. J Microbiol Biotechnol 14, 205-211.

Kim, B. S., Oh, H. M., Kang, H. \& Chun, J. (2005). Archaeal diversity in tidal flat sediment as revealed by $16 \mathrm{~S}$ rDNA analysis. J Microbiol 43, 144-151.

Kim, S., Jeong, H., Kim, S. \& Chun, J. (2006). Clostridium ganghwense sp. nov., isolated from tidal flat sediment. Int J Syst Evol Microbiol 56, 691-693.

Mountfort, D. O., Rainey, F. A., Burghardt, J. \& Stackebrandt, E. (1994). Clostridium grantii sp. nov., a new obligately anaerobic, alginolytic bacterium isolated from mullet gut. Arch Microbiol 162, 173-179.

Park, Y. D., Baik, K. S., Yi, H., Bae, K. S. \& Chun, J. (2005). Pseudoalteromonas byunsanensis sp. nov., isolated from tidal flat sediment in Korea. Int J Syst Evol Microbiol 55, 2519-2523.

Powers, E. M. (1995). Efficacy of the Ryu nonstaining KOH technique for rapidly determining gram reactions of food-borne and waterborne bacteria and yeasts. Appl Environ Microbiol 61, 3756-3758.

Saitou, N. \& Nei, M. (1987). The neighbor-joining method: a new method for reconstructing phylogenetic trees. Mol Biol Evol 4, 406-425.

Swofford, D. L. (1998). PAUP* ${ }^{*}$ phylogenetic analysis using parsimony (* and other methods), version 4.0. Sunderland, MA: Sinauer Associates.

Yi, H. \& Chun, J. (2006). Thalassobius aestuarii sp. nov., isolated from tidal flat sediment. J Microbiol 44, 171-176. 